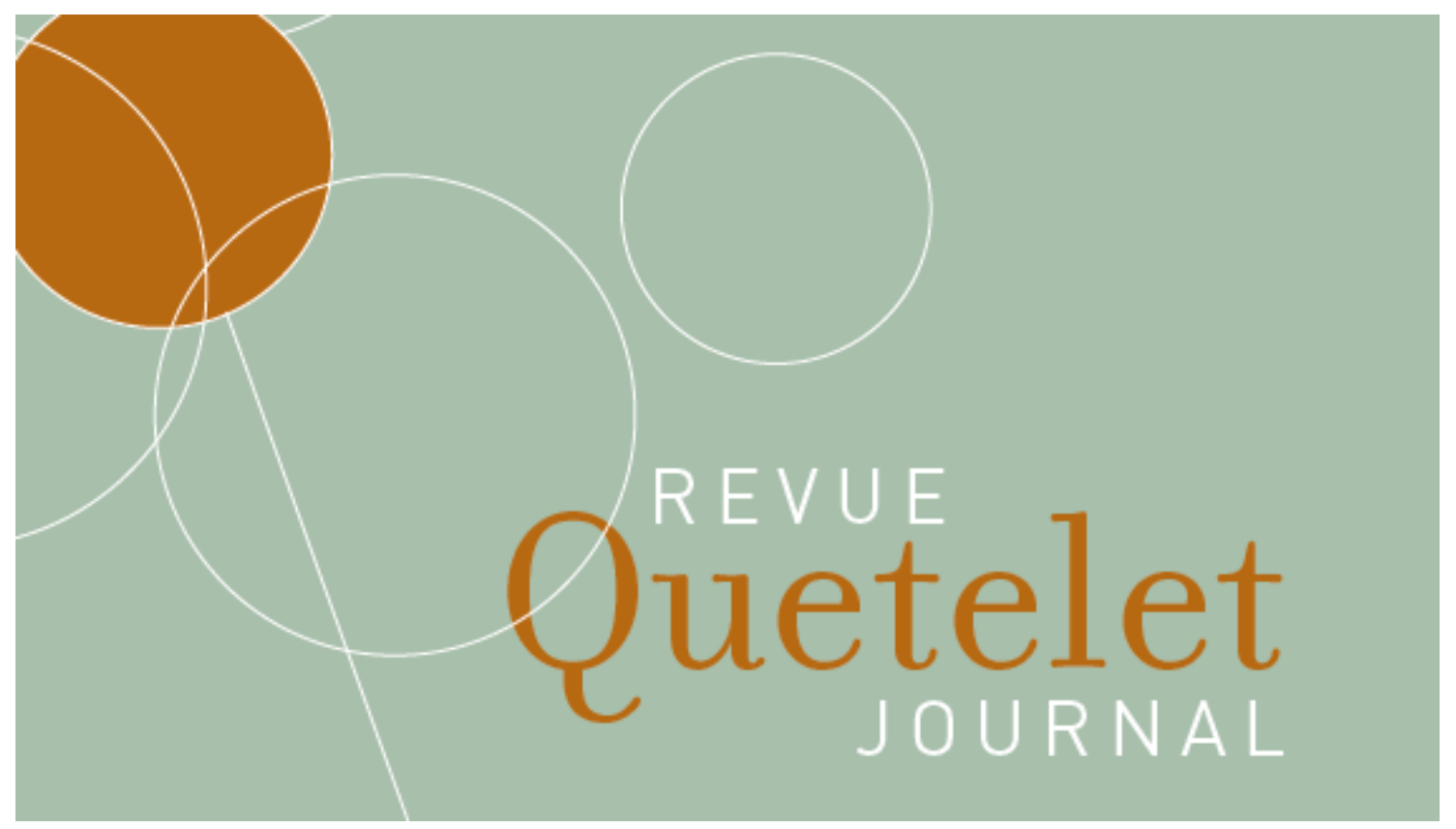

Vol. 7, $n^{\circ} 1,2019$, pp. 135-162

DOI : $10.14428 /$ rqj2019.07.01.05

ISSN: 2593-9157

\title{
Evidencing the gap between health expectancy and life expectancy for ethnic groups in Scotland
}

Geneviève Cézard

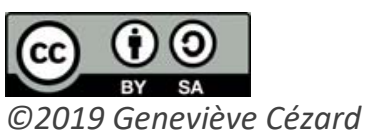

This work is licensed under a Creative Commons Attribution-NonCommercial 4.0 International License. You can share, adapt the material for non-commercial purposes provided that you give appropriate credit and indicate if changes were made. For details see https://creativecommons.org/licenses/by-sa/4.0/

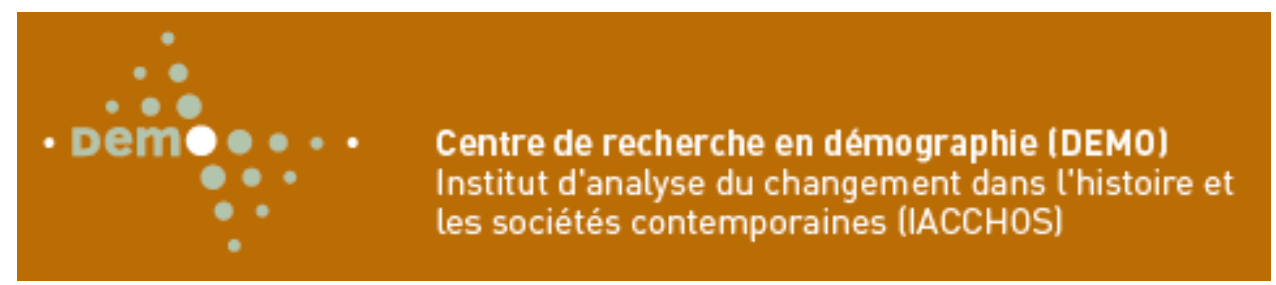





\title{
Evidencing the gap between health expectancy and life expectancy for ethnic groups in Scotland
}

\author{
Geneviève CÉZARD ${ }^{1}$
}

\begin{abstract}
Résumé
Objectif : Une étude récente a montré que les minorités ethniques vivent plus longtemps que le groupe ethnique majoritaire d'origine écossaise en Écosse. Cet avantage en termes de mortalité chez les minorités ethniques n'est pas un cas unique à l'Écosse. Cependant, à ce jour, on ignore si ces tendances de mortalité par groupe ethnique s'alignent avec celles de la morbidité par groupe ethnique. Par conséquent, cette étude explore les différences d'espérance de vie en santé (EVS) entre groupes ethniques en Écosse et compare ces tendances avec celles de l'espérance de vie (EV) pour ces mêmes groupes ethniques.

Méthodes : L'étude "Scottish Health and Ethnicity Linkage study» apparie de façon anonyme le recensement écossais 2001 de 4,6 millions de personnes à leurs données de mortalité. Ce recensement collecte deux mesures de santé perçue, le groupe ethnique auto-déclaré, l'âge et le sexe. A partir de la table de survie utilisée pour le calcul de l'espérance de vie par groupe ethnique et par sexe en Écosse, la méthode Sullivan a permis de calculer deux mesures d'espérance de vie en santé (l'espérance de vie en bonne santé et l'espérance de vie sans incapacité). Les intervalles de confiance (95\%) permettent de détecter si des différences d'espérance de vie en santé existent de façon significative chez certains groupes ethniques en comparaison avec la population d'origine écossaise, population prise comme référence.

Résultats : De plus longues espérances de vie en bonne santé et sans incapacité sont observées chez les hommes et les femmes d'origine britannique (non écossaise), $d^{\prime}$ 'autre origine caucasienne, d'origine chinoise ainsi que chez les hommes d'origine indienne en comparaison avec la population d'origine écossaise. Les populations pakistanaises et les hommes d'origine mixte ont les espérances de vie en bonne santé et sans incapacité les plus courtes. Les tendances d'espérance de vie en bonne santé et sans incapacité par groupe ethnique s'alignent de façon générale sur les tendances d'espérance de vie par groupe ethnique à l'exception du groupe pakistanais
\end{abstract}

1. Population and Health Research Group (PHRG), School of Geography and Sustainable Development (SGSD), University of St Andrews, UK. 
ayant parmi les plus longues espérances de vie, mais également les plus courtes espérances de vie en santé. Comparant EVS et EV, le nombre d'années en mauvaise santé est plus grand chez les femmes que chez les hommes pour l'ensemble des groupes ethniques. Par ailleurs, les populations pakistanaises et indiennes ont le plus grand nombre d'années en mauvaise santé en Écosse. Quant aux femmes pakistanaises, elles présentent le plus fort désavantage à ce niveau.

Conclusion : Les populations pakistanaises ont les espérances de vie en bonne santé et sans incapacité les plus courtes en Écosse. Ceci contraste avec leur avantage en termes de mortalité puisqu'elles ont les plus longues espérances de vie en Écosse. Un tel contraste mérite une exploration approfondie de ses déterminants. Cela permettrait aux gouvernements de s'assurer que des soins équitables et adaptés soient proposés, afin d'offrir une meilleure qualité de vie aux populations les plus vulnérables.

\title{
Mots-clés
}

Espérance de vie en santé, ethnicité, paradoxe morbidité-mortalité, Écosse.

\begin{abstract}
Background: Recent evidence has shown that ethnic minorities live longer than the majority population in Scotland. This mortality advantage in ethnic minorities is not unique to Scotland. However, whether morbidity patterns by ethnicity align with mortality patterns by ethnicity is unknown. Thus, this study explores ethnic differences in health expectancies (HE) in Scotland and contrasts HE with life expectancy (LE) findings.

Methods: The Scottish Health and Ethnicity Linkage study anonymously links the Scottish Census 2001 for 4.6 million people to mortality records. The Scottish Census 2001 collected two measures of self-assessed health, self-declared ethnicity, age, and sex. Utilising the life tables used to calculate life expectancy by ethnicity and sex in Scotland, the Sullivan method was employed to calculate two measures of health expectancy (healthy life expectancy and disability-free life expectancy) by ethnicity and sex. 95\% confidence intervals were calculated to detect significant differences compared to the majority White Scottish population, taken as reference.

Results: Longer health expectancies were found in males and females of Other White British, Other White, and Chinese origins as well as in Indian males compared to White Scottish populations. Any Mixed Background and Pakistani populations had the shortest healthy life expectancies. Patterns of health expectancy by ethnicity mostly aligned with patterns of life expectancy by ethnicity with the clear exception of the Pakistani population who showed among the longest life expectancies with the shortest health expectancies. Contrasting HE with LE findings, the number of years in an unhealthy state was greater in females than in males for each ethnic group. In relation to ethnicity, Pakistani and Indian populations had the highest number of years in an unhealthy state in Scotland. Pakistani females showed the strongest disadvantage in this respect.
\end{abstract}


Conclusion: Pakistani populations had the shortest health expectancies contrasting with the longest life expectancies in Scotland. Future research should aim to understand why such a discrepancy occurs while policy makers ensure that fair and adapted care is provided to offer better quality of life for the most vulnerable.

\section{Keywords}

Health expectancy, ethnicity, morbidity-mortality paradox, Scotland.

\section{Introduction}

Longer life expectancies have been found in most minority ethnic groups compared to the majority White Scottish population in Scotland (Gruer et al., 2016). Assuming greater deprivation in ethnic minorities compared to the majority population, one might not expect minority populations to fare so well in this regard. However, the Scottish context has its specificities and some evidence suggests that ethnic minorities do not necessarily experience lower socio-economic conditions compared to the majority in Scotland (Walsh, 2017). Furthermore, evidence in the Scottish context supports lower all-cause mortality in ethnic minorities beyond socio-economic differences (Bhopal et al., 2018). This mortality advantage phenomenon in ethnic minorities relative to the majority population is not unique to Scotland. For example, a mortality advantage has been shown in Hispanic populations in the US comparative to their low socio-economic status, often referred to as the "Hispanic mortality paradox» (Abraído-Lanza et al., 2005; Arias et al., 2010; Elo et al., 2004; Markides, Eschbach, 2005; Ruiz et al., 2013). In Europe, there is also a growing body of evidence on a «migrant mortality advantage» although with variation across countries and migrant groups (Aldridge et al., 2018; Anson, 2004; Brahimi, 1980; Deboosere, Gadeyne, 2005; Gadd et al., 2006; Ikram et al., 2016; Khlat, Darmon, 2003; Khlat, Guillot, 2017; Marmot et al., 1984; Moncho et al., 2015; Syse et al., 2018; Uitenbroek, Verhoeff, 2002; Wallace, Kulu, 2015). The reasons for this phenomenon are not fully understood. Key explanations offered as underlying the mortality advantage observed in Hispanics in the US and in specific migrant groups in Europe range from health selection hypotheses such as the «healthy migrant effect» (positive in selection) and the "salmon bias» (negative out selection) (Abraido-Lanza et al., 1999; Norredam et al., 2015; Rubalcava et al., 2008; Tarnutzer, Bopp, 2012; Turra, Elo, 2008; Ullmann et al., 2011; Wallace, Kulu, 2018), culturally protective health behaviours (AbraídoLanza et al., 2005; Fenelon, 2013) and data artefacts (Elo et al., 2004; 
Kibele et al., 2008; Razum et al., 2000; Smith, Bradshaw, 2006; Wallace, Kulu, 2014).

Nevertheless, this mortality advantage in specific ethnic minorities and migrant groups in varied contexts is particularly surprising as evidence based on general morbidity points to a disadvantage in some of those same groups in Scotland (Scottish Government, 2004, 2015; Whybrow et al., 2012), in the UK (Becares, 2013; Darlington et al., 2015; Sproston, Mindell, 2006) and other high income countries (Hayward et al., 2014; Lindström et al., 2001; Solé-Auró, Crimmins, 2008). For example, Pakistani women have the longest life expectancy in Scotland (Gruer et al., 2016) while initial general morbidity evidence from Scottish government reports points to poorer reported health in Pakistani populations (Scottish Government, 2004, 2015). This discrepancy in the evidence related to morbidity and mortality patterns should direct researchers to question whether living longer aligns with living longer healthily. Furthermore, to reduce health inequalities and ensure better quality of life for all, there is a need to better characterise ethnic inequalities in morbidity and mortality simultaneously which can then inform policy makers and feed into planning appropriate care services for the most vulnerable.

Some researchers have started to gather evidence and explore more generally whether the mortality advantage observed in specific populations aligns with their morbidity patterns. So far, a morbidity-mortality contrast appears in Greek and Italian populations in Australia (KourisBlazos, 2002; Kouris-Blazos, Itsiopoulos, 2014; Stanaway et al., 2018) and in Mediterranean migrants both in Belgium (De Grande et al., 2014; Deboosere, Gadeyne, 2005) and in France (Khlat, Guillot, 2017). In these studies, the observed mortality patterns and morbidity patterns were mostly gathered from different sources and did not necessarily refer to the same individuals. Some recent studies have also explored differences in healthy life expectancy between a specific ethnic or migrant group and the majority population (Carnein et al., 2014; Hayward et al., 2014). Although their aim was not necessarily to identify a morbidity-mortality contrast, these studies showed that both Turkish migrants in Germany and Hispanics in the US had similar or longer life expectancy compared to the majority population while showing more years with limitations or disability.

A systematic literature review of studies investigating health expectancies (HE) inequalities in older ages found that HE measures were used to compare the health of different subpopulations using variables such as gender, social class, race/ethnicity and health behaviours (Pongiglione et al., 2015). The review highlighted that evidence related to the study of HE 
differences by ethnic or race groups came uniquely from the US context. In addition to studies identified in the review, a few recent European studies have explored HE by ethnic or migrant groups (Carnein et al., 2014; Reus-Pons et al., 2017; Wohland et al., 2015). Thus, evidence of ethnic inequalities in HE remains limited worldwide. Most of this body of research used the Sullivan method. This method requires cross-sectional data which can combine morbidity and mortality from different sources. Indeed, available studies of HE by ethnicity gathered data on morbidity and mortality from different data and population sources. Mortality data came from official life tables or death registry while health data came primarily from surveys in both the US and European studies.

This study aims to identify whether a morbidity-mortality contrast appears in specific minority ethnic groups in Scotland. Identifying those who are living longer but in poorer health is key to planning for adapted care and services. This paper uses the Sullivan method to calculate two health expectancy (HE) measures: healthy life expectancy (HLE) and disability-free life expectancy (DFLE). HE measures by ethnicity enable us to assess how long ethnic groups are expected to live in good health. HE estimates are also useful if contrasted with life expectancy (LE) estimates. Doing so will provide us with a quantification of the contrast between reported health and mortality.

Previously published LE estimates by ethnicity in Scotland were derived from the Scottish Health and Ethnicity Linkage Study (SHELS) (Gruer et al., 2016). The HE calculation in this study uses the same data source, SHELS, since it holds individual level data from the Scottish Census 2001, containing two measures of self-assessed health (SAH), linked to mortality data. Thus, SHELS contains both reported morbidity and mortality data for 4.6 million people who responded to the Scottish Census in 2001. SAH is widely used and accepted as a reliable measure of health due to its strong association with other health indicators such as measures of physical and mental health, physician ratings of health, health care usage and mortality (Cohen et al., 1995; Idler, Benyamini, 1997; Idler, Kasl, 1995; Larue et al., 1979; Miilunpalo et al., 1997; Mossey, Shapiro, 1982; Wannamethee, Shaper, 1991). SAH has also been shown to be consistently associated with other measures of morbidity across ethnic groups in the UK setting (Chandola, Jenkinson, 2000).

As well as addressing hitherto unanswered questions about ethnic differences in contrasting morbidity-mortality patterns in Scotland, this study makes methodological contributions. Gathering data on health, mortality and ethnicity at the national level to enable health expectancy calculation by ethnicity is a challenge. In England and Wales, one study investigated 
health expectancies by ethnicity but HE estimations were based on an indirect method of mortality estimation by ethnicity due to the absence of data gathering mortality and ethnicity together (Wohland et al., 2015). In the US and Europe, a few studies have calculated HE by ethnicity (Carnein et al., 2014; Hayward et al., 2014) or by migrant status (Reus-Pons et al., 2017) but they used different samples and sources to gather morbidity and mortality data. Thanks to the linkage of death records to census data at a national level in the SHELS data, this is the first time that health expectancies by ethnicity have been calculated using a direct method and with morbidity and mortality data based on the same population source.

The research questions are as follows:

- What are the magnitude and direction of ethnic differences in health expectancies based on a direct method using individually linked data?

- Do patterns of ethnic differences in health expectancies differ from patterns of ethnic differences in life expectancy in Scotland (i.e. is there a morbiditymortality paradox)?

In line with initial evidence of ethnic differences in SAH in Scotland (Scottish Government, 2004, 2015), ethnic differences in HLE and DFLE are expected to go in both directions compared to the majority White Scottish population. For example, evidence based on the Scottish censuses of 2001 and 2011 consistently showed comparatively worse reported health in the Pakistani population and better reported health in the Chinese population. Therefore, we might expect to find shorter health expectancies in the Pakistani population and longer health expectancies in the Chinese population compared to the White Scottish population. If such a disadvantage in HLE and DFLE is found in the Pakistani population in Scotland, it will contrast with their LE advantage and translate into more years in an unhealthy state.

\section{Data and methods}

\section{Data}

SHELS linked the Scottish Census 2001 to death records for 4.6 million people (94\% of those who responded to the Scottish Census in 2001). Linkage of the Scottish Census 2001 to the Scottish Community Health Index (CHI) was done using probability matching and was described in detail (Bhopal et al., 2010). This resulted in a look-up table with encrypted $\mathrm{CHI}$ and encrypted census numbers enabling anonymous linkage 
between census, health and mortality records. The census part of the SHELS data contains two SAH indicators as well as self-declared ethnicity, sex and age. The linked mortality part of SHELS was used in combination with SAH to calculate two health expectancy measures.

\section{Ethnicity}

The Scottish Census 2001 data offer 14 ethnic categories for self-identification: White Scottish, White Irish, Other White British, Other White, Any Mixed Background, Indian, Pakistani, Bangladeshi, Other South Asian, Caribbean, African, Black Scottish or Other Black, Chinese and All Other Ethnic Groups. Disaggregation is preferred to disentangle the patterns and specificities of each ethnic group in the most refined way possible. However, when SAH was combined with mortality to produce health expectancies (HLE and DFLE), some ethnic groups were aggregated due to a low number of deaths. The HE analysis shared the same constraint of low death events for some groups as the LE published results (Gruer et al., 2016). Consequently, ethnic groups followed the same aggregation process. Bangladeshis were grouped with Other South Asians. Caribbean, Black African and Black Scottish and Other Black were combined into one group, labelled «African Origin». The results for the «All Other Ethnic Groups» are not reported due to the heterogeneity of this category.

\section{Self-Assessed Health measures}

The Scottish Census 2001 collected two SAH indicators: Self-Reported Health (SRH) and Limiting Long Term Illness (LLTI). The question related to SRH in the Scottish Census 2001 was as follows «Over the last twelve months would you say your health has on the whole been» with the opportunity to answer «good», «fairly good» or «not good». The question related to LLTI asked: «Do you have any long-term illness, health problem or disability which limits your daily activities or the work you can do? Include problems which are due to old age». This question could be answered with «yes» or «no». SRH (categories «good» and «fairly good» combined) and LLTI («no») were used to calculate the rate of good health which was included into an augmented life table to estimate health expectancies. Healthy life expectancy was estimated using SRH and disability-free life expectancy using LLTI. 
Life table

Life expectancy by ethnicity was previously published and its method of calculation explained (Gruer et al., 2016). It followed the Office of National Statistics recommendations in relation to life expectancy estimation for small populations using 3 years of data (Toson, Baker, 2003). It was based on 3 years of mortality data following the Scottish Census 2001 (May 2001 to April 2004), with the 4.6 million people of the SHELS cohort as the denominator in year 1 and adjusted denominators in years 2 and 3 accounting for any record of death or exit from Scotland. The Chiang II method (Chiang, 1984) and abridged life tables were used with 5-year age intervals and a category for new-borns aged 0 , for young children aged 1 to 4 years old and for older people aged 85 years old and above. LE estimates at birth were calculated with their 95\% confidence intervals (CI) by sex and ethnic group based on the SHELS population. The HE calculation builds on this calculation of life expectancy at birth and the corresponding period life table to calculate HLE and DFLE using the Sullivan method (Sullivan, 1971). The resulting augmented life tables incorporated the rate of good health calculated from SRH and LLTI to obtain respectively HLE and DFLE by sex and ethnic group. HE estimates and their 95\% CIs were calculated following the practical guide developed by the European Health Expectancy Monitoring Unit (EHEMU) (Jagger et al., 2006). In addition to LE at birth, results were also presented at 65 years of age to assess whether ethnic inequalities are consistent in older ages. To provide a better picture of potential discrepancies between LE estimates and HLE/DFLE estimates, the number of years in poor health (LE minus HLE) and the number of years lived with disability (LE minus DFLE) and their CIs were calculated for each sex and ethnic group. The proportion of years lived in good health (HLE divided by LE) and the proportion of years lived without disability (DFLE divided by LE) were also provided as an indication of relative length of life lived in a healthy state.

\section{Results}

\section{Ethnic differences in health expectancies in Scotland}

Figure 1 shows HLE and DFLE estimates at birth with 95\% CI by ethnicity and sex. Precise estimates are also available in Table 1, in column 4 for HLE at birth and column 5 for DFLE at birth. In the White Scottish population (taken as reference: dotted line in Figure 1), HLE at birth was 67.4 
years for males and 70.7 years for females. DFLE at birth was 59.4 years for males and 61.9 years for females of White Scottish origin. The expected number of years living disability-free (DFLE) was about 7 years shorter than the expected number of years living healthily (HLE) in the reference population. White Scottish females had significantly (CIs do not overlap) longer health expectancies at birth (both HLE and DFLE) than White Scottish males. It is worth noting that in all ethnic groups, females had longer (not necessarily significantly) HLE and DFLE at birth than their male counterparts with the exception of Indian and Pakistani females.

In males, HLE at birth was significantly longer in Other White British, Other White, Indian and Chinese ethnic groups compared to the White Scottish population. Chinese males had the longest HLE at birth (73.1 years), almost 6 years over that of White Scottish males. In contrast, HLE at birth was significantly shorter in males of White Irish (66.3 years), Any Mixed Background (64.7 years) and Pakistani (65.7 years) origins compared to the reference group. In females, HLE at birth was significantly longer in Other White British, Other White and Chinese populations compared to the reference group. Pakistani females had the shortest HLE at birth (64.2 years), 6.5 years shorter than that of the White Scottish females.

DFLE findings showed similar ethnic patterns to HLE findings in males i.e. there was significantly longer DFLE at birth in Other White British, Other White, Indian and Chinese males while DFLE at birth was shorter in White Irish, Any Mixed Background and Pakistani males. In females, there were similar ethnic patterns in DFLE as in HLE with longer DFLE at birth in Other White British, Other White and Chinese females and shorter DFLE in Pakistani females. In addition to HLE patterns, DFLE results also showed significantly shorter DFLE at birth in Any Mixed Background and for Indian females compared to the reference group. 
Figure 1 Life expectancy*, Healthy Life Expectancy and Disability-Free Life Expectancy at birth $(95 \% \mathrm{Cl})$ by ethnicity and sex
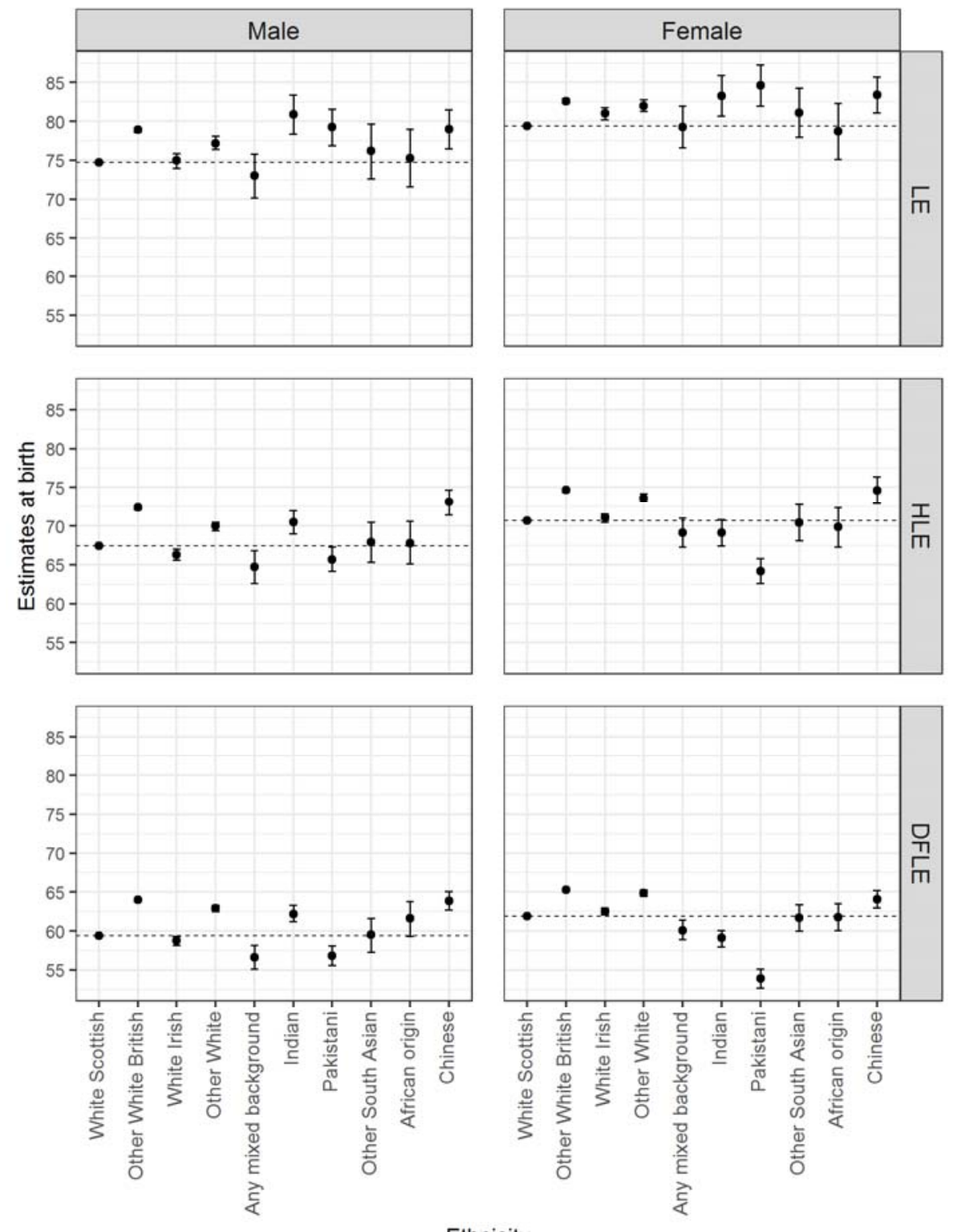

Ethnicity

* Note that life expectancy estimates were previously published (Gruer et al., 2016). 
TABLE 1 Health expectancies (HLE and DFLE) and Life expectancy (LE)* at birth $(95 \% \mathrm{Cl})$ by ethnicity and sex in Scotland, 2001-2004

\begin{tabular}{|c|c|c|c|c|c|c|c|c|}
\hline 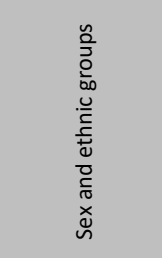 & 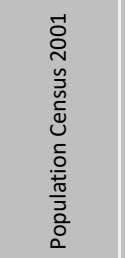 & 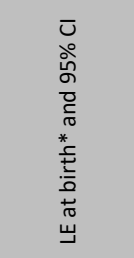 & 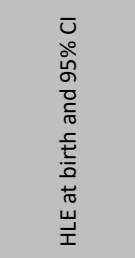 & 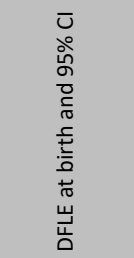 & 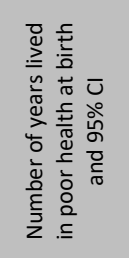 & 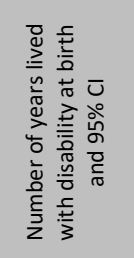 & 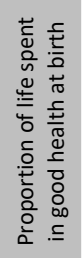 & 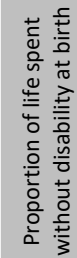 \\
\hline \multicolumn{9}{|l|}{ Males } \\
\hline White Scottish & $1^{\prime} 949^{\prime} 480$ & $\begin{array}{c}74.7 \\
{[74.6,74.8]}\end{array}$ & $\begin{array}{c}67.4 \\
{[67.3,67.5]}\end{array}$ & $\begin{array}{c}59.4 \\
{[59.3,59.4]}\end{array}$ & $\begin{array}{c}7.3 \\
{[7.3,7.4]}\end{array}$ & $\begin{array}{c}15.3 \\
{[15.3,15.4]}\end{array}$ & $90.2 \%$ & $79.5 \%$ \\
\hline $\begin{array}{l}\text { Other White } \\
\text { British }\end{array}$ & $160 \prime 235$ & $\begin{array}{c}78.9 \\
{[78.6,79.2]}\end{array}$ & $\begin{array}{c}72.4 \\
{[72.1,72.6]}\end{array}$ & $\begin{array}{c}64.0 \\
{[63.8,64.2]}\end{array}$ & $\begin{array}{c}6.5 \\
{[6.4,6.6]}\end{array}$ & $\begin{array}{c}15.0 \\
{[14.8,15.1]}\end{array}$ & $91.7 \%$ & $81.1 \%$ \\
\hline White Irish & $20^{\prime} 340$ & $\begin{array}{c}75.0 \\
{[74.0,75.9]}\end{array}$ & $\begin{array}{c}66.3 \\
{[65.6,67.0]}\end{array}$ & $\begin{array}{c}58.8 \\
{[58.2,59.3]}\end{array}$ & $\begin{array}{c}8.7 \\
{[8.4,9.0]}\end{array}$ & $\begin{array}{c}16.2 \\
{[15.7,16.7]}\end{array}$ & $88.4 \%$ & $78.4 \%$ \\
\hline Other White & $29^{\prime} 945$ & $\begin{array}{c}77.2 \\
{[76.4,78.1]}\end{array}$ & $\begin{array}{c}70.0 \\
{[69.4,70.5]}\end{array}$ & $\begin{array}{c}62.9 \\
{[62.5,63.3]}\end{array}$ & $\begin{array}{c}7.3 \\
{[6.9,7.6]}\end{array}$ & $\begin{array}{c}14.4 \\
{[13.9,14.9]}\end{array}$ & $90.6 \%$ & $81.4 \%$ \\
\hline $\begin{array}{l}\text { Any Mixed } \\
\text { Background }\end{array}$ & $5^{\prime} 310$ & $\begin{array}{c}73.0 \\
{[70.2,75.8]}\end{array}$ & $\begin{array}{c}64.7 \\
{[62.6,66.8]}\end{array}$ & $\begin{array}{c}56.6 \\
{[55.1,58.2]}\end{array}$ & $\begin{array}{c}8.3 \\
{[7.3,9.3]}\end{array}$ & $\begin{array}{c}16.4 \\
{[14.8,18.0]}\end{array}$ & $88.6 \%$ & $77.6 \%$ \\
\hline Indian & $6^{\prime} 450$ & $\begin{array}{c}80.9 \\
{[78.4,83.4]}\end{array}$ & $\begin{array}{c}70.5 \\
{[69.0,72.0]}\end{array}$ & $\begin{array}{c}62.2 \\
{[61.2,63.3]}\end{array}$ & $\begin{array}{c}10.4 \\
{[9.1,11.8]}\end{array}$ & $\begin{array}{c}18.7 \\
{[16.9,20.5]}\end{array}$ & $87.1 \%$ & $76.9 \%$ \\
\hline Pakistani & $12^{\prime} 930$ & $\begin{array}{c}79.3 \\
{[76.9,81.6]}\end{array}$ & $\begin{array}{c}65.7 \\
{[64.2,67.3]}\end{array}$ & $\begin{array}{c}56.8 \\
{[55.6,58.1]}\end{array}$ & $\begin{array}{c}13.6 \\
{[12.4,14.7]}\end{array}$ & $\begin{array}{c}22.5 \\
{[21.0,23.9]}\end{array}$ & $82.9 \%$ & $71.7 \%$ \\
\hline $\begin{array}{l}\text { Other South } \\
\text { Asian }\end{array}$ & $3^{\prime} 550$ & $\begin{array}{c}76.2 \\
{[72.6,79.7]}\end{array}$ & $\begin{array}{c}67.9 \\
{[65.3,70.5]}\end{array}$ & $\begin{array}{c}59.5 \\
{[57.3,61.6]}\end{array}$ & $\begin{array}{c}8.3 \\
{[6.9,9.6]}\end{array}$ & $\begin{array}{c}16.7 \\
{[14.8,18.6]}\end{array}$ & $89.1 \%$ & $78.1 \%$ \\
\hline African origin & $3 ’ 275$ & $\begin{array}{c}75.3 \\
{[71.6,79.0]}\end{array}$ & $\begin{array}{c}67.8 \\
{[65.1,70.6]}\end{array}$ & $\begin{array}{c}61.6 \\
{[59.3,63.8]}\end{array}$ & $\begin{array}{c}7.5 \\
{[6.3,8.7]}\end{array}$ & $\begin{array}{c}13.8 \\
{[12.0,15.6]}\end{array}$ & $90.0 \%$ & $81.7 \%$ \\
\hline Chinese & $6^{\prime} 530$ & $\begin{array}{c}79.0 \\
{[76.5,81.5]}\end{array}$ & $\begin{array}{c}73.1 \\
{[71.4,74.7]}\end{array}$ & $\begin{array}{c}63.9 \\
{[62.7,65.1]}\end{array}$ & $\begin{array}{c}5.9 \\
{[4.8,7.0]}\end{array}$ & $\begin{array}{c}15.1 \\
{[13.4,16.7]}\end{array}$ & $92.5 \%$ & $80.9 \%$ \\
\hline \multicolumn{9}{|l|}{ Females } \\
\hline White Scottish & $2^{\prime} 138^{\prime} 640$ & $\begin{array}{c}79.4 \\
{[79.3,79.5]}\end{array}$ & $\begin{array}{c}70.7 \\
{[70.7,70.8]}\end{array}$ & $\begin{array}{c}61.9 \\
{[61.8,61.9]}\end{array}$ & $\begin{array}{c}8.7 \\
{[8.7,8.7]}\end{array}$ & $\begin{array}{c}17.5 \\
{[17.5,17.6]}\end{array}$ & $89.1 \%$ & $77.9 \%$ \\
\hline $\begin{array}{l}\text { Other White } \\
\text { British }\end{array}$ & $174^{\prime} 750$ & $\begin{array}{c}82.6 \\
{[82.3,82.9]}\end{array}$ & $\begin{array}{c}74.7 \\
{[74.4,74.9]}\end{array}$ & $\begin{array}{c}65.3 \\
{[65.1,65.5]}\end{array}$ & $\begin{array}{c}7.9 \\
{[7.8,8.0]}\end{array}$ & $\begin{array}{c}17.3 \\
{[17.1,17.4]}\end{array}$ & $90.4 \%$ & $79.1 \%$ \\
\hline White Irish & $23^{\prime} 160$ & $\begin{array}{c}81.0 \\
{[80.2,81.8]}\end{array}$ & $\begin{array}{c}71.1 \\
{[70.5,71.6]}\end{array}$ & $\begin{array}{c}62.5 \\
{[62.1,63.0]}\end{array}$ & $\begin{array}{c}9.9 \\
{[9.6,10.3]}\end{array}$ & $\begin{array}{c}18.5 \\
{[18.0,19.0]}\end{array}$ & $87.7 \%$ & $77.2 \%$ \\
\hline Other White & $35^{\prime} 710$ & $\begin{array}{c}82.0 \\
{[81.3,82.8]}\end{array}$ & $\begin{array}{c}73.6 \\
{[73.1,74.2]}\end{array}$ & $\begin{array}{c}64.9 \\
{[64.5,65.3]}\end{array}$ & $\begin{array}{c}8.4 \\
{[8.1,8.7]}\end{array}$ & $\begin{array}{c}17.2 \\
{[16.7,17.6]}\end{array}$ & $89.8 \%$ & $79.1 \%$ \\
\hline $\begin{array}{l}\text { Any Mixed } \\
\text { Background }\end{array}$ & $5^{\prime} 800$ & $\begin{array}{c}79.3 \\
{[76.6,82.0]}\end{array}$ & $\begin{array}{c}69.1 \\
{[67.3,71.0]}\end{array}$ & $\begin{array}{c}60.1 \\
{[58.9,61.4]}\end{array}$ & $\begin{array}{c}10.2 \\
{[9.1,11.3]}\end{array}$ & $\begin{array}{c}19.2 \\
{[17.4,20.9]}\end{array}$ & $87.2 \%$ & $75.8 \%$ \\
\hline Indian & $5^{\prime} 890$ & $\begin{array}{c}83.3 \\
{[80.7,85.9]}\end{array}$ & $\begin{array}{c}69.1 \\
{[67.4,70.8]}\end{array}$ & $\begin{array}{c}59.1 \\
{[58.0,60.1]}\end{array}$ & $\begin{array}{c}14.2 \\
{[12.8,15.6]}\end{array}$ & $\begin{array}{c}24.2 \\
{[22.3,26.2]}\end{array}$ & $83.0 \%$ & $70.9 \%$ \\
\hline Pakistani & $12^{\prime} 700$ & $\begin{array}{c}84.6 \\
{[82.0,87.3]}\end{array}$ & $\begin{array}{c}64.2 \\
{[62.6,65.8]}\end{array}$ & $\begin{array}{c}53.9 \\
{[52.7,55.1]}\end{array}$ & $\begin{array}{c}20.4 \\
{[18.7,22.1]}\end{array}$ & $\begin{array}{c}30.7 \\
{[28.7,32.7]}\end{array}$ & $75.9 \%$ & $63.7 \%$ \\
\hline $\begin{array}{l}\text { Other South } \\
\text { Asian }\end{array}$ & $2 ' 965$ & $\begin{array}{c}81.1 \\
{[78.0,84.3]}\end{array}$ & $\begin{array}{c}70.4 \\
{[68.1,72.8]}\end{array}$ & $\begin{array}{c}61.7 \\
{[60.0,63.4]}\end{array}$ & $\begin{array}{c}10.7 \\
{[9.4,12.0]}\end{array}$ & $\begin{array}{c}19.5 \\
{[17.4,21.5]}\end{array}$ & $86.8 \%$ & $76.0 \%$ \\
\hline African origin & 3'055 & $\begin{array}{c}78.7 \\
{[75.1,82.3]}\end{array}$ & $\begin{array}{c}69.9 \\
{[67.3,72.4]}\end{array}$ & $\begin{array}{c}61.8 \\
{[60.1,63.5]}\end{array}$ & $\begin{array}{c}8.9 \\
{[7.4,10.3]}\end{array}$ & $\begin{array}{c}16.9 \\
{[14.6,19.2]}\end{array}$ & $88.8 \%$ & $78.5 \%$ \\
\hline Chinese & $6^{\prime} 670$ & $\begin{array}{c}83.4 \\
{[81.1,85.7]}\end{array}$ & $\begin{array}{c}74.6 \\
{[72.9,76.4]}\end{array}$ & $\begin{array}{c}64.1 \\
{[63.0,65.2]}\end{array}$ & $\begin{array}{c}8.8 \\
{[7.8,9.8]}\end{array}$ & $\begin{array}{c}19.3 \\
{[17.6,20.9]}\end{array}$ & $89.5 \%$ & $76.9 \%$ \\
\hline
\end{tabular}


Contrary to published LE estimates at birth where most minority ethnic groups were expected to live longer than the White Scottish majority (Gruer et al., 2016), ethnic patterns in HLE and DFLE showed differences going both ways. As expected the Chinese population experienced an advantage in health expectancies and the Pakistani population a disadvantage. Shorter health expectancies were also found in White Irish and Any Mixed Background males compared to White Scottish males. The use of DFLE (but not HLE) revealed a significant disadvantage (shorter disability-free life expectancy) in Any Mixed Background and Indian females compared to White Scottish females.

\section{The contrasted patterns of ethnic differences in HLE/DFLE and LE in Scotland}

Figure 1 and Table 1 (column 3) present previously published LE at birth by ethnicity in Scotland. In this section, patterns of health expectancies at birth by ethnicity are contrasted with patterns of life expectancy at birth by ethnicity. As explained earlier, ethnic patterns in HLE and DFLE showed differences going both ways which contrasts with published LE estimates at birth where most minority ethnic groups showed an advantage (longer LE at birth) compared to the White Scottish majority (Gruer et al., 2016).

In males, Indian (80.9 years), Pakistani (79.3 years) followed by Chinese (79.0 years) and Other White British (78.9 years) populations had the longest LE at birth while Any Mixed Background (73.0 years) and White Scottish (74.7 years) males had the shortest. However, in terms of health expectancies (Table 1, columns 4 and 5), the longest HLE and DFLE were found in Chinese and Other White British males and the lowest in Any Mixed Background and Pakistani males. Albeit less marked than their LE advantage, Indian males had significantly longer HLE and DFLE compared to White Scottish males. Hence, a consistent advantage in LE and HLE/DFLE was observed in Other White British, Chinese and Indian males and a consistent disadvantage in Any Mixed Background males. Only Pakistani males broke this pattern, with one of the longest LE at birth combined with the shortest HLE (65.7 years) and DFLE (56.8 years) at birth. Similarly, in females, Pakistani (84.6 years), Chinese (83.4 years), Indian (83.3 years) and Other White British (82.6 years) populations had the longest LE at birth while Any Mixed Background (79.3 years), White Scottish (79.4 years) and African origin (78.7 years) females had the shortest. In line with LE results, a significant advantage in HLE and DFLE at birth appeared in Other White British and Chinese females. However, 
in contrast to their longest LE at birth, Indian and Pakistani females had the shortest HLE and DFLE.

In summary, patterns of ethnic differences in LE at birth and in HLE and DFLE at birth are mostly consistent. However, Pakistani males and females and Indian females had among the longest LE at birth contrasting with the shortest HLE and DFLE at birth.

\section{Quantification of the gap between HLE/DFLE and LE}

Table 1 presents a descriptive quantification of the differences between LE and HLE/DFLE through the estimated number of years lived in poor health (LE minus HLE) or with disability (LE minus DFLE) as well as through the proportion of years lived in good health (HLE divided by LE) or without disability (DFLE divided by LE). Figure 2 shows a visualisation of the number of years in poor health and the number of years with disability by ethnicity and sex.

In males, the number of years lived in poor health was 7.3 years in the White Scottish population and ranged from 5.9 years in Chinese males to 13.6 years in Pakistani males. In females, the number of years lived in poor health was 8.7 years in the White Scottish population and ranged from 8.4 years in Other White females to 20.4 years in Pakistani females. The number of years lived in poor health was greater in females than in males for all ethnic groups. Most ethnic groups had around 6-9 years lived in poor health in males and 8-11 years in females with the clear exception of Indian (10.4 years in males, 14.2 years in females) and Pakistani (13.6 years in males, 20.4 years in females) populations. Results in relation to years lived with disability showed similar patterns of a higher number of years in an unhealthy state in Indian (18.7 years in males, 24.2 years in females) and Pakistani populations (22.5 years in males, 30.7 years in females). Most ethnic groups had around 14-17 years lived with disability in males and 17-20 years in females. Looking at the same problem through the proportion of life spent in good health or without disability provided similar conclusions. The lowest percentages of life spent healthily was found in males and females of Indian and Pakistani origins. The most striking disadvantage was seen in Pakistani females with only $75.9 \%$ of life spent in good health and $63.7 \%$ of life spent without disability compared to $89.1 \%$ and $77.9 \%$ respectively for White Scottish females. 
FIGURE 2 Number of years in poor health or with disability by ethnicity and sex
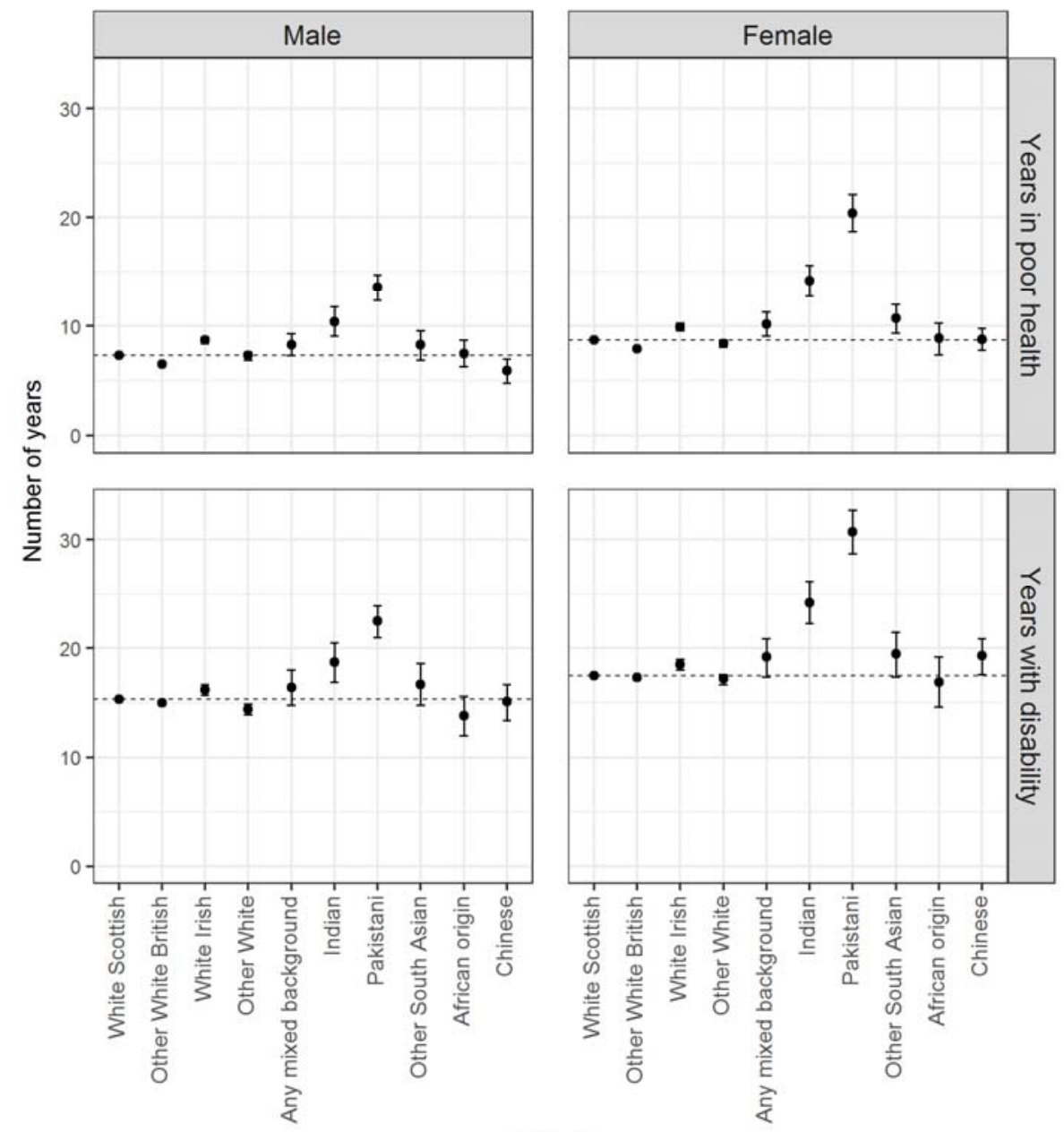

Ethnicity 
TABLE 2 Health expectancies (HLE and DFLE) and Life expectancy (LE)* at $65(95 \% \mathrm{Cl})$ by ethnicity and sex in Scotland, 2001-2004

\begin{tabular}{|c|c|c|c|c|c|c|c|}
\hline 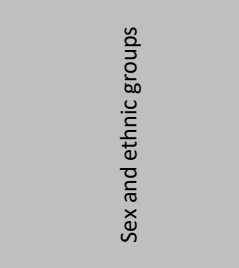 & 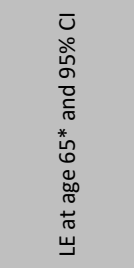 & 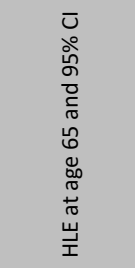 & 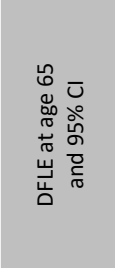 & 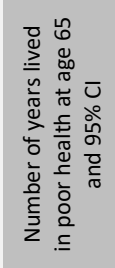 & 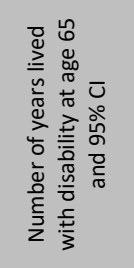 & 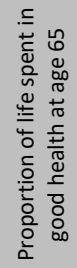 & 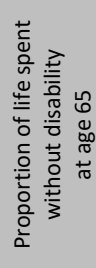 \\
\hline \multicolumn{8}{|l|}{ Males } \\
\hline White Scottish & $\begin{array}{c}15.2 \\
{[15.2,15.3]}\end{array}$ & $\begin{array}{c}11.8 \\
{[11.8,11.9]}\end{array}$ & $\begin{array}{c}6.9 \\
{[6.9,7.0]}\end{array}$ & $\begin{array}{c}3.4 \\
{[3.4,3.4]}\end{array}$ & $\begin{array}{c}8.3 \\
{[8.2,8.3]}\end{array}$ & $77.7 \%$ & $45.6 \%$ \\
\hline Other White British & $\begin{array}{c}17.2 \\
{[17.0,17.5]}\end{array}$ & $\begin{array}{c}13.8 \\
{[13.6,13.9]}\end{array}$ & $\begin{array}{c}8.3 \\
{[8.1,8.4]}\end{array}$ & $\begin{array}{c}3.5 \\
{[3.4,3.6]}\end{array}$ & $\begin{array}{c}9.0 \\
{[8.8,9.1]}\end{array}$ & $79.9 \%$ & $47.9 \%$ \\
\hline White Irish & $\begin{array}{c}15.2 \\
{[14.6,15.7]}\end{array}$ & $\begin{array}{c}10.9 \\
{[10.6,11.2]}\end{array}$ & $\begin{array}{c}6.3 \\
{[6.0,6.5]}\end{array}$ & $\begin{array}{c}4.3 \\
{[4.0,4.5]}\end{array}$ & $\begin{array}{c}8.9 \\
{[8.5,9.2]}\end{array}$ & $71.9 \%$ & $41.4 \%$ \\
\hline Other White & $\begin{array}{c}15.9 \\
{[15.2,16.5]}\end{array}$ & $\begin{array}{c}11.9 \\
{[11.4,12.3]}\end{array}$ & $\begin{array}{c}7.3 \\
{[7.0,7.6]}\end{array}$ & $\begin{array}{c}4.0 \\
{[3.7,4.3]}\end{array}$ & $\begin{array}{c}8.6 \\
{[8.1,9.0]}\end{array}$ & $74.8 \%$ & $45.9 \%$ \\
\hline Any Mixed Background & $\begin{array}{c}14.0 \\
{[12.1,16.0]}\end{array}$ & $\begin{array}{c}11.4 \\
{[10.1,12.8]}\end{array}$ & $\begin{array}{c}6.7 \\
{[5.7,7.7]}\end{array}$ & $\begin{array}{c}2.6 \\
{[1.8,3.5]}\end{array}$ & $\begin{array}{c}7.4 \\
{[6.1,8.6]}\end{array}$ & $81.5 \%$ & $47.6 \%$ \\
\hline Indian & $\begin{array}{c}19.3 \\
{[16.9,21.6]}\end{array}$ & $\begin{array}{c}12.6 \\
{[11.3,14.0]}\end{array}$ & $\begin{array}{c}7.0 \\
{[6.1,7.8]}\end{array}$ & $\begin{array}{c}6.6 \\
{[5.2,8.0]}\end{array}$ & $\begin{array}{c}12.3 \\
{[10.5,14.1]}\end{array}$ & $65.5 \%$ & $36.2 \%$ \\
\hline Pakistani & $\begin{array}{c}18.1 \\
{[15.8,20.4]}\end{array}$ & $\begin{array}{c}11.1 \\
{[9.6,12.6]}\end{array}$ & $\begin{array}{c}6.8 \\
{[5.6,8.0]}\end{array}$ & $\begin{array}{c}7.0 \\
{[5.8,8.2]}\end{array}$ & $\begin{array}{c}11.3 \\
{[9.8,12.8]}\end{array}$ & $61.4 \%$ & $37.5 \%$ \\
\hline Other South Asian & $\begin{array}{c}17.1 \\
{[14.0,20.3]}\end{array}$ & $\begin{array}{c}12.8 \\
{[10.6,15.0]}\end{array}$ & $\begin{array}{c}7.4 \\
{[5.5,9.3]}\end{array}$ & $\begin{array}{c}4.4 \\
{[3.0,5.7]}\end{array}$ & $\begin{array}{c}9.7 \\
{[7.9,11.5]}\end{array}$ & $74.5 \%$ & $43.3 \%$ \\
\hline African origin & $\begin{array}{c}15.5 \\
{[12.3,18.7]}\end{array}$ & $\begin{array}{c}11.9 \\
{[9.6,14.2]}\end{array}$ & $\begin{array}{c}8.3 \\
{[6.4,10.1]}\end{array}$ & $\begin{array}{c}3.7 \\
{[2.5,4.9]}\end{array}$ & $\begin{array}{c}7.3 \\
{[5.5,9.0]}\end{array}$ & $76.4 \%$ & $53.3 \%$ \\
\hline Chinese & $\begin{array}{c}16.7 \\
{[14.3,19.1]}\end{array}$ & $\begin{array}{c}13.2 \\
{[11.7,14.8]}\end{array}$ & $\begin{array}{c}7.3 \\
{[6.2,8.3]}\end{array}$ & $\begin{array}{c}3.5 \\
{[2.3,4.7]}\end{array}$ & $\begin{array}{c}9.5 \\
{[7.8,11.2]}\end{array}$ & $79.1 \%$ & $43.4 \%$ \\
\hline \multicolumn{8}{|l|}{ Females } \\
\hline White Scottish & $\begin{array}{c}18.2 \\
{[18.1,18.2]}\end{array}$ & $\begin{array}{c}13.8 \\
{[13.8,13.8]}\end{array}$ & $\begin{array}{c}7.9 \\
{[7.9,7.9]}\end{array}$ & $\begin{array}{c}4.4 \\
{[4.3,4.4]}\end{array}$ & $\begin{array}{c}10.3 \\
{[10.2,10.3]}\end{array}$ & $76.0 \%$ & $43.6 \%$ \\
\hline Other White British & $\begin{array}{c}20.1 \\
{[19.9,20.4]}\end{array}$ & $\begin{array}{c}15.6 \\
{[15.5,15.8]}\end{array}$ & $\begin{array}{c}8.9 \\
{[8.8,9.0]}\end{array}$ & $\begin{array}{c}4.5 \\
{[4.4,4.6]}\end{array}$ & $\begin{array}{c}11.2 \\
{[11.1,11.4]}\end{array}$ & $77.6 \%$ & $44.3 \%$ \\
\hline White Irish & $\begin{array}{c}19.2 \\
{[18.7,19.7]}\end{array}$ & $\begin{array}{c}13.6 \\
{[13.3,13.9]}\end{array}$ & $\begin{array}{c}7.7 \\
{[7.5,7.9]}\end{array}$ & $\begin{array}{c}5.6 \\
{[5.4,5.9]}\end{array}$ & $\begin{array}{c}11.5 \\
{[11.1,11.8]}\end{array}$ & $70.6 \%$ & $40.1 \%$ \\
\hline Other White & $\begin{array}{c}19.6 \\
{[19.0,20.1]}\end{array}$ & $\begin{array}{c}14.4 \\
{[14.1,14.8]}\end{array}$ & $\begin{array}{c}8.3 \\
{[8.1,8.6]}\end{array}$ & $\begin{array}{c}5.1 \\
{[4.8,5.4]}\end{array}$ & $\begin{array}{c}11.2 \\
{[10.8,11.6]}\end{array}$ & $73.9 \%$ & $42.5 \%$ \\
\hline Any Mixed Background & $\begin{array}{c}18.5 \\
{[16.4,20.5]}\end{array}$ & $\begin{array}{c}13.5 \\
{[12.1,14.8]}\end{array}$ & $\begin{array}{c}7.3 \\
{[6.4,8.2]}\end{array}$ & $\begin{array}{c}5.0 \\
{[4.0,6.0]}\end{array}$ & $\begin{array}{c}11.1 \\
{[9.7,12.6]}\end{array}$ & $73.0 \%$ & $39.8 \%$ \\
\hline Indian & $\begin{array}{c}20.5 \\
{[18.0,23.0]}\end{array}$ & $\begin{array}{c}12.0 \\
{[10.4,13.6]}\end{array}$ & $\begin{array}{c}4.7 \\
{[3.8,5.7]}\end{array}$ & $\begin{array}{c}8.5 \\
{[7.2,9.9]}\end{array}$ & $\begin{array}{c}15.7 \\
{[13.9,17.6]}\end{array}$ & $58.4 \%$ & $23.2 \%$ \\
\hline Pakistani & $\begin{array}{c}23.0 \\
{[20.5,25.6]}\end{array}$ & $\begin{array}{c}11.6 \\
{[10.1,13.2]}\end{array}$ & $\begin{array}{c}5.2 \\
{[4.0,6.3]}\end{array}$ & $\begin{array}{c}11.4 \\
{[9.7,13.1]}\end{array}$ & $\begin{array}{c}17.9 \\
{[15.9,19.8]}\end{array}$ & $50.5 \%$ & $22.4 \%$ \\
\hline Other South Asian & $\begin{array}{c}18.4 \\
{[15.7,21.2]}\end{array}$ & $\begin{array}{c}14.3 \\
{[12.3,16.3]}\end{array}$ & $\begin{array}{c}8.7 \\
{[7.3,10.1]}\end{array}$ & $\begin{array}{c}4.1 \\
{[3.0,5.2]}\end{array}$ & $\begin{array}{c}9.7 \\
{[7.9,11.5]}\end{array}$ & $77.7 \%$ & $47.3 \%$ \\
\hline African origin & $\begin{array}{c}17.7 \\
{[14.4,21.1]}\end{array}$ & $\begin{array}{c}13.2 \\
{[10.9,15.5]}\end{array}$ & $\begin{array}{c}7.2 \\
{[5.7,8.6]}\end{array}$ & $\begin{array}{c}4.5 \\
{[3.1,5.9]}\end{array}$ & $\begin{array}{c}10.6 \\
{[8.3,12.8]}\end{array}$ & $74.5 \%$ & $40.4 \%$ \\
\hline Chinese & $\begin{array}{c}21.6 \\
{[19.6,23.6]}\end{array}$ & $\begin{array}{c}15.7 \\
{[14.2,17.2]}\end{array}$ & $\begin{array}{c}7.9 \\
{[7.0,8.9]}\end{array}$ & $\begin{array}{c}5.9 \\
{[4.9,6.8]}\end{array}$ & $\begin{array}{c}13.6 \\
{[12.1,15.1]}\end{array}$ & $72.8 \%$ & $36.9 \%$ \\
\hline
\end{tabular}

* The life expectancy at 65 years by ethnic group was not previously published but was taken from the life table used to calculate LE at birth (Gruer et al., 2016). It is included in column 3 and used in combination with HLE and DFLE for further calculation. 


\section{Ethnic inequalities in LE and HLE/DFLE at 65 years}

This section considers whether the estimates of LE and HE at 65 years are consistent with findings described previously using estimates at birth. In line with patterns at birth, results at 65 years (Table 2) showed longer LE at 65 years in Indian and Pakistani populations compared to the White Scottish population. LE at 65 years was 19.3 years in Indian males and 18.1 years in Pakistani males compared to 15.2 years in White Scottish males. For females, LE at 65 years was 23.0 years in Pakistani and 20.5 years in Indian populations compared to 18.2 years in White Scottish females. Findings at 65 years consistently showed an advantage in LE in the Chinese population although no longer significantly in males.

Such a LE advantage in older ages in minority ethnic groups compared to the majority ethnic group of Scotland again contrasted with health expectancies findings. A significant disadvantage in both HLE and DFLE was found in Indian and Pakistani females. Chinese males and females no longer showed an advantage in DFLE at older ages but had similar levels of DFLE compared to the White Scottish population.

In line with the findings at birth, the quantification of the contrast between LE and HLE/DFLE at 65 years highlighted a disadvantage in males and females of Pakistani and Indian origins. At 65 years, Pakistani females had the highest estimated number of years in an unhealthy state with 11.4 years in poor health and 17.9 years with disability compared to, respectively, 4.4 years and 10.3 years in White Scottish females. A disadvantage also emerged in Chinese females. The findings showed that Chinese females had longer LE at 65 years (21.6 years) along with similar DFLE at birth to that of White Scottish females, and thus live more years with disability (13.6 years).

\section{Discussion}

This study has shown ethnic differences in health expectancies in Scotland in both directions compared to the majority White Scottish population: an advantage was observed in males and females of Other White British, Other White and Chinese origins as well as in Indian males, while Any Mixed Background and Pakistani males and females had a clear health expectancy disadvantage. Overall, patterns of ethnic differences in HLE and DFLE at birth were in line with previously published life expectancy patterns by ethnicity in Scotland (Gruer et al., 2016). 
However, the findings of this paper have highlighted a clear contrast between the LE advantage and the corresponding HLE and DFLE patterns for Pakistani and Indian populations. The number of years lived in poor health and with disability were greater in females than males for all ethnic groups. If considered with ethnicity, results were particularly concerning for Indian and Pakistani populations, especially for females: they were living longer but in poorer health. The worst outcome was found in Pakistani females: 20.4 years lived in poor health, 30.7 years with disability. Results at birth and at 65 years consistently showed that individuals spent longer periods in an unhealthy state in Pakistani and Indian populations compared to the majority White Scottish population.

Advocating the usefulness of healthy life expectancy as a measure of health inequalities (beyond the sole use of life expectancy), Scotland has been producing HE figures for the last few decades (Scottish Government, 2019; Wood et al., 2006). Based on multiple sources, the latest figures produced and released by the Scottish Government report HE by sex, Scottish council areas, health boards and area-level deprivation (Scottish Government, 2019). However, monitoring progress in tackling health inequalities requires the investigation of various dimensions of social inequalities. No measure of healthy life expectancy by disability, ethnicity, origin, religion or individual socio-economic circumstances is available in the Scottish context. Hence, this study is the first to provide HLE and DFLE estimates by ethnicity in Scotland. It also contributes to bridging the gap in quantifying health inequalities between social subgroups in Scotland.

Indeed, a major strength of this study is that it was based on the national sample size of SHELS linking reported morbidity to mortality data at an individual level. Therefore, the calculation of health expectancy by ethnicity was based on a direct method, gathering data from the same cohort of individuals and at a national level. Analysis was done on 10 ethnic groups in Scotland with a fine ethnic granularity. Due to low number of deaths, smaller ethnic groups were aggregated into Other South Asian and African origin groups. No difference in HE were found for these aggregated ethnic groups in comparison to the White Scottish population, potentially hiding divergent HE patterns for their subpopulations. LE and HE estimates could be directly contrasted by ethnicity which allowed the investigation of whether some ethnic groups have longer lives in worse health.

The unique strength of the data and methods of this paper has enabled it to offer clear initial evidence of a Pakistani morbidity-mortality paradox in the Scottish context. Pakistani populations lived longer but had rela- 
tively shorter healthy lives and consequently had more years in an unhealthy state than the White Scottish majority. This phenomenon was also seen in Indian populations in Scotland although to a lesser extent. This is the first time that evidence of such a morbidity-mortality discrepancy in particular ethnic groups has been demonstrated at a country level based on the same cohort. Previous research focusing on the morbiditymortality gap in specific ethnic groups gathered evidence from different sources and population samples or were based on small sample sizes (Deboosere, Gadeyne, 2005; Khlat, Guillot, 2017; Kouris-Blazos, 2002; Stanaway et al., 2018).

Whether this morbidity-mortality paradox is a real phenomenon in specific ethnic minorities in Scotland can be questioned exploiting the same type of arguments as for the morbidity-survival paradox observed in women compared to men (Arber, Cooper, 1999; Case, Paxson, 2005; Idler, Benyamini, 1997; Kulminski et al., 2008; Oksuzyan et al., 2018; Oksuzyan et al., 2008; Rieker, Bird, 2005; Van Oyen et al., 2013; Verbrugge, 1982). Doubts can be expressed about the accuracy of the morbidity and mortality data.

Firstly, the observed mortality advantage in most ethnic groups in Scotland could be due to a data artefact, the effect of selective moves on health (e.g. unhealthy return migration) and unrecorded emigration and death. For example, migrants, when getting older and sick, could decide to migrate back to their country of origin to finish their lives back home with their relatives. This unhealthy return migration phenomenon, often referred to as the "salmon bias», if combined with unrecorded emigrations and deaths, could bias mortality estimates by producing a mortality advantage where there is none. However, a salmon bias hypothesis seems unlikely in Pakistani and Indian populations in Scotland. In the SHELS cohort, around $60 \%$ of the Pakistani and half of the Indian populations were born in the UK, highlighting the well-settled nature of these populations. Furthermore, these ethnic groups have a strong sense of national belonging in the UK. Indeed, more than half of people from ethnic minorities in the UK describe their national identity as some form of UK identity with the highest proportions seen in South Asian and Black Caribbean populations (up to $84 \%$ in Pakistani populations) (Jivraj, Simpson, 2015). National Health Services in Scotland also offers health care services that are «free at the point of use». Hence, if South Asians living in Scotland are well-settled and can access free health care services when becoming ill, they are likely to stay to benefit from the health care they need. If most of their family and descendants are also settled in the UK, it would reduce even more their likelihood of returning to their country of origin in older 
ages. Little is known about the prevalence of the salmon bias in the UK and its contribution to the observed mortality advantage in ethnic minorities. One recent study showed that there was an unhealthy return migration phenomenon for specific ethnic groups in the UK but this phenomenon was not strong enough to explain the mortality advantage observed in South Asian populations in the UK (Wallace, Kulu, 2018).

Secondly, the reliability of the reported morbidity data can be challenged. One could argue that there can be language barriers or cultural differences in the reporting and meaning of health. In that case, we could assume that SAH as a subjective measure of health might not accurately reflect the objective health status of minority ethnic groups. Hence, such a reporting bias could result in biased morbidity estimates and possibly lower-than-expected HE estimates. Based on the Health Survey for England, Chandola and Jenkinson showed that worse reported health was associated with greater morbidity in all ethnic groups and for a range of more objective measures of health (Chandola, Jenkinson, 2000). Their analysis also supported no differential association between reported health and more objective morbidity across ethnic groups. Their findings supported a strong and consistent association between subjective morbidity and more objective morbidity across ethnic groups. However, on account of the present findings, further research is warranted to support claims of the consistency of the subjective-objective health link between ethnic groups in the Scottish context.

If we assume that a salmon bias cannot explain the mortality advantage in Pakistani and Indian populations in Scotland and that their reported morbidity reflects their objective health status, we could argue that there is a real morbidity-mortality paradox (i.e. living longer but in poorer health) in theses populations. Higher morbidity in certain groups could be due to differences in access and quality of care. Although, evidence from the Health Survey for England does not suggest unequal access to GP services for minority ethnic groups (Nazroo et al., 2009), available evidence both in England and Scotland suggests a more complex picture of potential unequal access operating at different level of healthcare and healthcare settings (Katikireddi et al., 2018; McFarland et al., 1989; Nazroo et al., 2009; Worth et al., 2009). Morbidity inequalities are less likely to be solely due to an ethnic differential in health services engagement. Nevertheless, this is an area for policy to consider. To explain the morbidity-mortality contrast, the sex morbidity-mortality paradox literature offers additional alternatives. Some groups could suffer from specific conditions that contribute to reporting higher morbidity as well as 
have lower risk of mortality (Case, Paxson, 2005). In the case of the Pakistani populations in the UK, they have a particular disease profile including higher risk of metabolic syndrome related diseases such as diabetes, renal disease and cardiovascular disease (CVD) (Bansal et al., 2013; Bhopal et al., 2011; Dreyer et al., 2009; Forouhi et al., 2006; Hull et al., 2011; Sproston, Mindell, 2006), higher risk of respiratory disease such as asthma (Sheikh et al., 2016) and lower risk of cancer (Bhopal et al., 2012) in comparison to their white counterparts. This disease profile (particularly their higher risk of CVD) does not fully fit with the expected set that contributes to higher morbidity and lower mortality. However, an emerging literature in the UK shows that South Asian populations, once diagnosed with either diabetes, renal disease or CVD survive longer than their white counterparts diagnosed with the same disease (Bansal et al., 2013; Davis et al., 2014; Mathur et al., 2018). In relation to the sex morbiditysurvival paradox, Oksuzyan and colleagues highlight that potential mechanisms can be complex and multifactorial including biological, social and psychological (Oksuzyan et al., 2018; Oksuzyan et al., 2008). Understanding mechanisms will require further research along these avenues.

Policy makers should aim to improve the quality of life of Pakistani and Indian populations in Scotland and ensure that fair and culturally-adapted care is provided in primary and secondary care settings while the root causes of this paradox are pinpointed and better understood. Further research should investigate the underlying mechanisms of the morbiditymortality contrast observed and aim for a better characterisation of the diseases that drive a morbidity disadvantage but do not necessarily lead to worse survival rates.

\section{Acknowledgements}

I am grateful to Professor Raj Bhopal (former SHELS principal investigator), Professor Aziz Sheikh (current SHELS principal investigator), National Records of Scotland, the Public Benefit and Privacy Panel for Health and Social Care and the Administrative Data Research Network for the access to the SHELS data. I thank the School of Geography and Sustainable Development from the University of St Andrews for awarding me the St Leonard's and Geography \& Sustainable Development PhD studentship in order to study ethnic differences in health at the older ages in Scotland. My supervisors, Dr Alan Marshall, Professor Hill Kulu and Dr Nissa Finney supported me in my inquiries of ethnic health inequalities. They provided 
me with advices and feedbacks on my research and reviewed this manuscript prior to submission. Mary Carr provided English language support and proofread the manuscript. This paper including analysis and interpretation is my responsibility alone.

The SHELS study was approved by the Multicentre Research Ethics Committee for Scotland (REC 13/SS/0225) and the Privacy Advisory Committee of NHS National Services Scotland (PAC 36/13). The present work was conducted in addition to the initial SHELS research plan. Therefore, further ethical approval was sought and approved by the University Teaching and Research Ethics Committee, School of Geography and Geosciences, University of St Andrews in August 2017 (reference GG13084). An amendment to PAC 36/13 was also submitted and approved by the Public Benefit and Privacy Panel for Health and Social Care in November 2017. Individual consent was not sought. The anonymously linked SHELS data were accessed in a secure environment thanks to the Administrative Data Research Network (PROJ-208). Appropriate security clearance was required to carry out the analyses.

\section{References}

Abraído-lanza A. F., Chao M. T., Flórez K. R. (2005), «Do Healthy Behaviors Decline with Greater Acculturation?: Implications for the Latino Mortality Paradox», Social Science \& Medicine (1982), 61, pp. 1'243-1'255, https://doi.org/10.1016/j.socscimed. 2005.01.016.

Abraído-lanza A. F., Dohrenwend B. P., Ng-Mak D. S., Turner J. B. (1999), «The Latino Mortality Paradox: A Test of the 'Salmon Bias' and Healthy Migrant Hypotheses", Am J Public Health, 89, pp. 1'543-1'548, https://doi.org/10.2105/AJPH.89.10. 1543.

Aldridge R. W., Nellums l. B., Bartlett S., Barr A. L., Patel P., Burns R., Hargreaves S., Miranda J. J., Tollmans S., Friedland J. S., Abubakar I. (2018), "Global Patterns of Mortality in International Migrants: A Systematic Review and Meta-Analysis", The Lancet, 392, pp. 2'553-2'566, https://doi.org/10.1016/S0140-6736(18)32781-8.

Anson J. (2004), «The Migrant Mortality Advantage: A 70 Month Follow-up of the Brussels Population", European Journal of Population/Revue européenne de Démographie, 20, pp. 191-218, https://doi.org/10.1007/s10680-004-0883-1.

Arber S., Cooper H. (1999), "Gender Differences in Health in Later Life: The New Paradox?», Social Science \& Medicine, 48, pp. 61-76, https://doi.org/10.1016/S02779536(98)00289-5. 
Arias E., Eschbach K., Schauman W. S., Backiund E. L., Sorlie P. D. (2010), «The Hispanic Mortality Advantage and Ethnic Misclassification on US Death Certificates", American Journal of Public Health, 100, pp. S171-S177, https://doi.org/10.2105/ AJPH.2008.135863.

Bansal N., fischbacher C. M., Bhopal R. S., Brown H., Steiner M. F., Capewell S., SCOTTISH H., ETHNICITY LINKAGE S. (2013), «Myocardial Infarction Incidence and Survival by Ethnic Group: Scottish Health and Ethnicity Linkage Retrospective Cohort Study», BMJ Open, 3, e003415, https://doi.org/10.1136/bmjopen-2013-003415.

BeCARES L. (2013), «Which Ethnic Groups Have the Poorest Health - Ethnic Health Inequalities 1991 to 2011», The Dynamics of Diversity Series, The Centre on Dynamics of Ethnicity (CoDE), The University of Manchester.

Bhopal R., Fischbacher C., Povey C., Chalmers J., Mueller G., Steiner M., Brown H., BRewster D. H., BANSAL N. (2010), "Cohort Profile: Scottish Health and Ethnicity Linkage Study of 4.65 Million People Exploring Ethnic Variations in Disease in Scotland», International Journal of Epidemiology, 40, pp. 1'168-1'175, https://doi.org/10.1093/ ije/dyq118.

Bhopal R. S., Bansal N., Fischbacher C., Brown H., Capewell S. (2011), «Ethnic Variations in Chest Pain and Angina in Men and Women: Scottish Ethnicity and Health Linkage Study of 4.65 Million People», European Journal of Preventive Cardiology, 19, pp. 1'250-1'257, https://doi.org/10.1177/1741826711425775.

Bhopal R. S., Bansal N., Steiner M., Brewster D. H., Scottish H., Ethnicity linkage S. (2012), «Does the 'Scottish Effect' Apply to All Ethnic Groups? All-Cancer, Lung, Colorectal, Breast and Prostate Cancer in the Scottish Health and Ethnicity Linkage Cohort Study", BMJ Open, 2, https://doi.org/10.1136/bmjopen-2012-001957.

Bhopal R. S., Gruer l., Cezard G., Douglas A., Steiner M. F. C., Millard A., Buchanan D., KATIKIREdDIS. V., SHeikH A. (2018), «Mortality, Ethnicity, and Country of Birth on a National Scale, 2001-2013: A Retrospective Cohort (Scottish Health and Ethnicity Linkage Study)», PLOS Medicine, 15, e1002515, https://doi.org/10.1371/journal. pmed.1002515.

Brahımı M. (1980), "La mortalité des étrangers en France», Population (French Edition), pp. 603-622, https://doi.org/10.2307/1532400.

Carnein M., Milewski N., Doblhammer G., Nusselder W. J. (2014), «Health Inequalities of Immigrants: Patterns and Determinants of Health Expectancies of Turkish Migrants Living in Germany", Health Among the Elderly in Germany: New Evidence on Disease, Disability and Care Need. Leverkusen: Barbara Budrich, pp. 157-190.

CASE A., PAXson C. (2005), "Sex Differences in Morbidity and Mortality», Demography, 42, pp. 189-214, https://doi.org/10.1353/dem.2005.0011.

Chandola T., Jenkinson C. (2000), «Validating Self-rated Health in Different Ethnic Groups», Ethnicity \& Health, 5, pp. 151-159, https://doi.org/10.1080/713667451.

CHIANg C. L. (1984), The Life Table and Its Applications. 
Cohen G., Forbes J., Garraway M. (1995), «Interpreting Self Reported Limiting Long Term Illness», Bmj, 311, pp. 722-724, https://doi.org/10.1136/bmj.311.7007.722.

Darlington F., Norman P., Ballas D., Exeter D. J. (2015), «Exploring Ethnic Inequalities in Health: Evidence from the Health Survey for England, 1998-2011», Diversity \& Equality in Health and Care, https://doi.org/10.21767/2049-5471.100032.

Davis T. M., Coleman R. L., Holman R. R., Group U. (2014), «Ethnicity and Long-Term Vascular Outcomes in Type 2 Diabetes: A Prospective Observational Study (UKPDS 83)», Diabet Med, 31, pp. 200-207, https://doi.org/10.1111/dme.12353.

De Grande H., Vandenheede H., Gadeyne S., Deboosere P. (2014), «Health Status and Mortality Rates of Adolescents and Young Adults in the Brussels-Capital Region: Differences According to Region of Origin and Migration History", Ethnicity \& Health, 19, pp. 122-143, https://doi.org/10.1080/13557858.2013.771149.

Deboosere P., Gadeyne S. (2005), «Adult Migrant Mortality Advantage in Belgium: Evidence Using Census and Register Data», Population, 60, pp. 655-698, https://doi. org/10.3917/pope.505.0655.

Dreyer G., Hull S., Aitken Z., Chesser A., Yaqoob M. M. (2009), «The Effect of Ethnicity on the Prevalence of Diabetes and Associated Chronic Kidney Disease», QJM: An International Journal of Medicine, 102, pp. 261-269, https://doi.org/10.1093/qjmed/ hon177.

Elo I. T., Turra C. M., Kestenbaum B., Ferguson B. R. (2004), «Mortality Among Elderly Hispanics in the United States: Past Evidence and New Results», Demography, 41, pp. 109-128, https://doi.org/10.1353/dem.2004.0001.

Fenelon A. (2013), «Revisiting the Hispanic Paradox in the United States: The Role of Smoking», Social Science \& Medicine (1982), 82, pp. 1-9, https://doi.org/10.1016/j. socscimed.2012.12.028.

Forouhi N. G., Merrick D., Goyder E., Ferguson B. A., Abbas J., Lachowycz K., Wild S. H. (2006), «Diabetes Prevalence in England, 2001-Estimates from an Epidemiological Model», Diabet Med, 23, pp. 189-197, https://doi.org/10.1111/j.1464-5491.2005. 01787.x.

Gadd M., Johansson S.-E., SUndquist J., WÄndell P. (2006), «Are There Differences in All-Cause and Coronary Heart Disease Mortality between Immigrants in Sweden and in their Country of Birth? A Follow-Up Study of Total Populations", BMC Public Health, 6, 102, https://doi.org/10.1186/1471-2458-6-102.

Gruer l., Cezard G., Clark E., Douglas A., Steiner M., Millard A., Buchanan D., KATIKIREdD S. V., SHeikH A., Bhopal R. (2016), "Life Expectancy of Different Ethnic Groups Using Death Records Linked to Population Census Data for 4.62 Million People in Scotland», J Epidemiol Community Health, https://doi.org/10.1136/jech2016-207426. 
hayward M. D., hummer R. A., Chiu C.-T., González-González C., Wong R. (2014), "Does the Hispanic Paradox in US Adult Mortality Extend to Disability?», Population Research and Policy Review, 33, pp. 81-96, https://doi.org/10.1007/s11113-0139312-7.

Hull S., Dreyer G., Badrick E., Chesser A., Yaqoob M. M. (2011), «The Relationship of Ethnicity to the Prevalence and Management of Hypertension and Associated Chronic Kidney Disease», BMC nephrology, 12, 41, https://doi.org/10.1186/1471-2369-1241.

IDLER E. L., BenYAMINI Y. (1997), «Self-Rated Health and Mortality: A Review of Twenty-Seven Community Studies", Journal of Health and Social Behavior, 38, pp. 21-37, https://doi.org/10.2307/2955359.

IDLER E. L., KASL S. V. (1995), "Self-Ratings of Health: Do they also Predict change in Functional Ability?», The Journals of Gerontology: Series B, 50B, pp. S344-S353, https://doi.org/10.1093/geronb/50B.6.S344.

Ikram U. Z., Mackenbach J. P., Harding S., Rey G., Bhopal R. S., Regidor E., Rosato M., Juel K., Stronks K., Kunst A. E. (2016), «All-Cause and Cause-Specific Mortality of Different Migrant Populations in Europe», Eur J Epidemiol, 31, pp. 655-665, https://doi. org/10.1007/s10654-015-0083-9.

JAGger C., Cox B., Le Roy S. (2006), «Health Expectancy Calculation by the Sullivan Method: A Practical Guide», Third Edition. EHEMU Technical Report.

JivRAJ S., SIMPSON L. (2015), Ethnic Identity and Inequalities in Britain: The Dynamics of Diversity, Policy Press, https://doi.org/10.2307/j.ctt1t89504.

Katikireddi S. V., Cézard G., Bhopal R. S., Williams l., Douglas A., Millard A., Steiner M., Buchanan D., Sheikh A., Gruer L. (2018), «Assessment of Health Care, Hospital Admissions, and Mortality by Ethnicity: Population-Based Cohort Study of HealthSystem Performance in Scotland», The Lancet Public Health, https://doi.org/10. 1016/S2468-2667(18)30068-9.

Khlat M., DaRmon N. (2003), «Is There a Mediterranean Migrants Mortality Paradox in Europe?», International Journal of Epidemiology, 32, pp. 1'115-1'118, https://doi. org/10.1093/ije/dyg308.

Khlat M., Guillot M. (2017), «Health and Mortality Patterns Among Migrants in France», TROVATo F. (ed), Migration, Health and Survival: International Perspectives, Northampton, USA, Edward Elgar Publishers.

Kibele E., Scholz R., Shкolnikov V. M. (2008), «Low Migrant Mortality in Germany for Men Aged 65 and Older: Fact or Artifact?», European Journal of Epidemiology, 23, pp. 389-393, https://doi.org/10.1007/s10654-008-9247-1.

Kouris-Blazos A. (2002), «Morbidity Mortality Paradox of 1st Generation Greek Australians», Asia Pacific Journal of Clinical Nutrition, 11, https://doi.org/10.1046/j. 1440-6047.11.supp3.2.x. 
Kouris-Blazos A., Itsıopoulos C. (2014), «Low All-Cause Mortality Despite High Cardiovascular Risk in Elderly Greek-Born Australians: Attenuating Potential of Diet?», Asia Pacific Journal of Clinical Nutrition.

Kulminski A. M., Culminskaya I. V., Ukraintseva S. V., Arbeev K. G., Land K. C., Yashin A. I. (2008), «Sex-Specific Health Deterioration and Mortality: The Morbidity-Mortality Paradox over Age and Time», Experimental Gerontology, 43, 1052-1057, https:// doi.org/10.1016/j.exger.2008.09.007.

larue A., Bank L., Jarvik U., Hetland M. (1979), "Health in Old Age: How Do Physicians' Ratings and Self-ratings Compare?», Journal of Gerontology, 34, pp. 687-691, https://doi.org/10.1093/geronj/34.5.687.

LindSTRÖM M., SUndquist J., Östergren P.-O. (2001), «Ethnic Differences in Self Reported Health in Malmö in Southern Sweden ", Journal of Epidemiology and Community Health, 55, pp. 97-103, https://doi.org/10.1136/jech.55.2.97.

MARKIDES K. S., EsCHBACH K. (2005), «Aging, Migration, and Mortality: Current Status of Research on the Hispanic Paradox», The Journals of Gerontology Series B: Psychological Sciences and Social Sciences, 60, pp. S68-S75, https://doi.org/10.1093/ geronb/60.Special_Issue_2.S68.

Marmot M. G., Adelstein A. M., Bulusu L. (1984), «Lessons from the Study of Immigrant Mortality", Lancet, 1, pp. 1'455-1'457.

Mathur R., Dreyer G., Yaqoob M. M., Hull S. A. (2018), «Ethnic Differences in the Progression of Chronic Kidney Disease and Risk of Death in a UK Diabetic Population: an Observational Cohort Study», BMJ Open, 8, https://doi.org/10.1136/bmjopen2017-020145.

Mcfarland E., Dalton M., Walsh D. (1989), «Ethnic Minority Needs and Service Delivery: The Barriers to Access in a Glasgow Inner-City Area», Journal of Ethnic and Migration Studies, 15, pp. 405-415, https://doi.org/10.1080/1369183X.1989.9976128.

Millunpalo S., Vuori I., Oja P., Pasanen M., URPonen H. (1997), «Self-Rated Health Status as a Health Measure: The Predictive Value of Self-Reported Health Status on the Use of Physician Services and on Mortality in the Working-Age Population», Journal of Clinical Epidemiology, 50, pp. 517-528, https://doi.org/10.1016/S08954356(97)00045-0.

Moncho J., Pereyra-Zamora P., Nolasco A., Tamayo-Fonseca N., Melchor I., Macia L. (2015), "Trends and Disparities in Mortality Among Spanish-Born and Foreign-Born Populations Residing in Spain, 1999-2008», Journal of Immigrant and Minority Health, 17, pp. 1'374-1'384, https://doi.org/10.1007/s10903-014-0081-0.

Mossey J. M., ShAPIRo E. (1982), «Self-Rated Health: A Predictor of Mortality Among the Elderly", American Journal of Public Health, 72, pp. 800-808, https://doi.org/10. 2105/AJPH.72.8.800. 
Nazroo J. Y., Falaschetti E., Pierce M., Primatesta P. (2009), «Ethnic Inequalities in Access to and Outcomes of Healthcare: Analysis of the Health Survey for England", Journal of Epidemiology \& Community Health, 63, pp. 1'022-1'027, https://doi.org/ 10.1136/jech.2009.089409.

Norredam M., hansen O. H., Petersen J. H., Kunst A. E., Kristiansen M., Krasnik A. (2015), «Remigration of Migrants with Severe Disease: Myth or Reality? A RegisterBased Cohort Study", Eur J Public Health, 25, https://doi.org/10.1093/eurpub/ cku138.

OKsuzyan A., GumÀ J., Doblhammer G. (2018), "Sex Differences in Health and Survival», A Demographic Perspective on Gender, Family and Health in Europe. Springer, https://doi.org/10.1007/978-3-319-72356-3.

Oksuzyan A., Juel K., Vaupel J. W., Christensen K. (2008), «Men: Good Health and High Mortality. Sex Differences in Health and Aging», Aging Clinical and Experimental Research, 20, pp. 91-102, https://doi.org/10.1007/BF03324754.

Pongiglione B., De Stavola B. L., Ploubidis G. B. (2015), «A Systematic Literature Review of Studies Analyzing Inequalities in Health Expectancy among the Older Population", PLOS ONE, 10, e0130747, https://doi.org/10.1371/journal.pone.0130747.

Razum O., Zeeb H., Rohrmann S. (2000), "The 'Healthy Migrant Effect' - Not Merely a Fallacy of Inaccurate Denominator Figures», International Journal of Epidemiology, 29, pp. 191-192, https://doi.org/10.1093/ije/29.1.191.

Reus-Pons M., Kibele E. U. B., JANSSEN F. (2017), «Differences in Healthy Life Expectancy between Older Migrants and Non-Migrants in Three European Countries over Time», International Journal of Public Health, 62, pp. 531-540, https://doi.org/10. 1007/s00038-017-0949-6.

Rieker P. P., BiRD C. E. (2005), «Rethinking Gender Differences in Health: Why We Need to Integrate Social and Biological Perspectives", The Journals of Gerontology: Series B, 60, pp. S40-S47, https://doi.org/10.1093/geronb/60.Special_Issue_2.S40.

Rubalcava L. N., Teruel G. M., Thomas D., Goldman N. (2008), «The Healthy Migrant Effect: New Findings From the Mexican Family Life Survey», American Journal of Public Health, 98, pp. 78-84., https://doi.org/10.2105/AJPH.2006.098418

Ruiz J. M., Steffen P., Smith T. B. (2013), «Hispanic Mortality Paradox: A Systematic Review and Meta-Analysis of the Longitudinal Literature", American Journal of Public Health, 103, pp. e52-e60, https://doi.org/10.2105/AJPH.2012.301103.

Scottish Government (2004), Analysis of Ethnicity in the 2001 Census - Summary Report, Edinburgh.

Scottish Government (2015), Which Ethnic Groups Have the Poorest Health? An Analysis of Health Inequality and Ethnicity in Scotland, Edinburgh.

Scottish Government (2019), Healthy Life Expectancy in Scottish Areas 2015-2017. 
Sheikh A., Steiner M. F., Cézard G., Bansal N., Fischbacher C., Simpson C. R., Douglas A., Bhopal R., ReseARChers S. (2016), «Ethnic Variations in Asthma Hospital Admission, Readmission and Death: A Retrospective, National Cohort Study of 4.62 Million People in Scotland", BMC Med, 14, 3, https://doi.org/10.1186/s12916-015-0546-6.

SMith D. P., Bradshaw B. S. (2006), «Rethinking the Hispanic Paradox: Death Rates and Life Expectancy for US Non-Hispanic White and Hispanic Populations», American Journal of Public Health, 96, pp. 1'686-1'692, https://doi.org/10.2105/AJPH.2003. 035378.

SolÉ-Auró A., Crimmins E. M. (2008), "Health of Immigrants in European Countries», International Migration Review, 42, pp. 861-876, https://doi.org/10.1111/j.17477379.2008.00150.x.

Sproston K., Mindell J. (2006), «Health Survey for England 2004. The Health of Minority Ethnic Groups».

Stanaway F., Blyth F., Cumming R., Naganathan V. (2018), «Morbidity-Mortality Paradox in Older Male Italian Migrants in Australia: The Concord Health and Ageing in Men Project», European Journal of Public Health, 28, cky047.007.

Suluivan D. F. (1971), "A Single Index of Mortality and Morbidity», HSMHA Health Rep, 86, pp. 347-54, https://doi.org/10.2307/4594169.

Syse A., Dzamarija M. T., Kumar B. N., Diaz E. (2018), «An Observational Study of Immigrant Mortality Differences in Norway by Reason for Migration, Length of Stay and Characteristics of Sending Countries", BMC Public Health, 18, 508, https://doi.org/10. 1186/s12889-018-5435-4.

TARNUTZER S., Bopp M. (2012), «Healthy Migrants but Unhealthy Offspring? A Retrospective Cohort Study Among Italians in Switzerland", BMC Public Health, 12, 1'104, https://doi.org/10.1186/1471-2458-12-1104.

TOSON B., BAKER A. (2003), «Life Expectancy at Birth: Methodological Options for Small Populations», National Statistics Methodological Series, 33.

TurRa C. M., Elo I. T. (2008), «The Impact of Salmon Bias on the Hispanic Mortality Advantage: New Evidence from Social Security Data», Popul Res Policy Rev, 27, pp. 515-530, https://doi.org/10.1007/s11113-008-9087-4.

Uitenbroek D. G., Verhoeff A. P. (2002), «Life Expectancy and Mortality Differences between Migrant Groups Living in Amsterdam, The Netherlands», Social Science \& Medicine, 54, pp. 1'379-1'388, https://doi.org/10.1016/S0277-9536(01)00120-4.

Ullmann S. H., Goldman N., Massey D. S. (2011), «Healthier before They Migrate, Less Healthy when They Return? The Health of Returned Migrants in Mexico», Social Science \& Medicine, 73, pp. 421-428, https://doi.org/10.1016/j.socscimed.2011.05. 037. 
Van Oyen H., Nusselder W., Jagger C., Kolip P., Cambois E., Robine J.-M. (2013), «Gender Differences in Healthy Life Years within the EU: An Exploration of the 'HealthSurvival' Paradox», International Journal of Public Health, 58, pp. 143-155, https:// doi.org/10.1007/s00038-012-0361-1.

Verbrugge L. M. (1982), "Sex Differentials in Health», Public Health Reports, 97, pp. 417-437.

Wallace M., Kulu H. (2014), "Low Immigrant Mortality in England and Wales: A Data Artefact?», Social Science \& Medicine, 120, pp. 100-109, https://doi.org/10.1016/j. socscimed.2014.08.032.

Wallace M., Kulu H. (2015), «Mortality Among Immigrants in England and Wales by Major Causes of Death, 1971-2012: A Longitudinal Analysis of Register-Based Data», Soc Sci Med, 147, pp. 209-21, https://doi.org/10.1016/j.socscimed.2015.10.060.

Wallace M., Kulu H. (2018), "Can the Salmon Bias Effect Explain the Migrant Mortality Advantage in England and Wales?», Population, Space and Place, 0, e2146, https://doi.org/10.1002/psp.2146.

WALSH D. (2017), The Changing Ethnic Profiles of Glasgow and Scotland, and the Implications for Population Health, Glasgow Centre for Population Health.

Wannamethee G., Shaper A. G. (1991), «Self-Assessment of Health Status and Mortality in Middle-Aged British Men», International Journal of Epidemiology, 20, pp. 239245, https://doi.org/10.1093/ije/20.1.239.

Whybrow P., Ramsay J., Macnee K. (2012), The Scottish Health Survey: Topic Report: Equality Groups, Scottish Government.

Wohland P., Rees P., Nazroo J., Jagger C. (2015), «Inequalities in Healthy Life Expectancy between Ethnic Groups in England and Wales in 2001», Ethn Health, 20, pp. 341-53, https://doi.org/10.1080/13557858.2014.921892.

Wood R., Sutton M., Clark D., Mckeon A., Bain M. (2006), «Measuring Inequalities in Health: The Case for Healthy Life Expectancy", Journal of Epidemiology and Community Health, 60, pp. 1'089-1'092, https://doi.org/10.1136/jech.2005.044941.

Worth A., Irshad T., Bhopal R., Brown D., Lawton J., Grant E., Murray S., Kendall M., AdAM J., GARDEE R. (2009), «Vulnerability and Access to Care for South Asian Sikh and Muslim Patients with Life Limiting Illness in Scotland: Prospective Longitudinal Qualitative Study", Bmj, 338, b183, https://doi.org/10.1136/bmj.b183. 